skaidrības, kā izpētīts, cik precīzi organizāciju normatīvie dokumenti tiek realizēti praksē) raidījumu subtitrēšanā, bet mazāk runāts par audio formātiem neredzīgajiem un vājredzīgajiem skatîtājiem, "vieglo" valodu vai citiem, moderno tehnologiju piedāvātiem risinājumiem. Tāpat nav analizētas zināmo risinājumu priekšrocības un trūkumi, kā arī izaicinājumi, ko tie sagādā raidorganizācijām, ieskaitot finansiālos izaicinājumus. Diskursa analīze pētījuma daḷā nespēj dod neko principiāli interesantu un jaunu salīdzinājumā ar teorētiskajām nodaḷām.

Diemžēl autors nav skaidrojis arī šo nodaḷu vietu kopīgajā darba mērķu sasniegšanas kontekstā. Nav skaidrs, kā aprakstītais Vācijas sabiedrisko mediju regulējums tieši nodrošina cilvēku ar invaliditāti integrāciju. Nav skaidrs, kā izpētītais korelē ar Latviju vai attiecināms uz citām valstīm - daudz detalizēta materiāla, kas nenoliedzami ir interesants, bet nav pierādīts, ko tas dod tieši šai tēmai vai, formulējot citādi, kā, piem., nosacījumi, kas radīti Vācijas sabiedrisko mediju sistēmā, invaliditātes sociālās konstruēšanas un cilvēku ar invaliditāti iesaistīšanas kontekstā varētu dot labāku rezultātu nekā morāli attīstīta, iejūtīga, godīga, solidāra un apzinīga mediju darbinieka intuitīvi pašregulatīivais darbs.

Tādēḷ arī secinājumi sanākuši vispārīgi un nekonstruktīvi, lai arī pārskatāmi strukturēti atsevišķi nostāju, mediju un specifiski arī sabiedrisko mediju līmenī. Tie formulēti idealizēti normatīvā diskursā - kā "vajag", nevis kā "ir" - un netiek līdz līmenim, kurā parādītos, kas "nepieciešams, lai būtu". Mazliet nepārdomāts liekas, piem., pēdējais secinājums: "Žestu valodai sabiedrisko mediju saturā jāienem valsts valodai līdzvērtīgas pozīcijas." N̦emot vērā, cik sarežǵīta ir šādu pozīciju "noturēšana", un ņemot vērā, ka vienlīdz nozīmīgi tad būtu pārstāvēt ar līdzīgām pozīcijām arī citus invaliditātes veidus, domāju, ka risinājumiem šajā jomā būtu jābūt mazāk regulatīviem, bet drīzāk orientētiem uz mediju vadības un visu profesiju darbinieku vērtībām un izpratni. Šo izpratni noteikti veicinātu arī R. Putna grāmatas apgūšana, kā arī īpašs atbalsts tālākiem pētījumiem par sabiedrisko mediju organizācijas principiem, saturu un diskursu kopumā attiecībā uz cilvēkiem ar invaliditāti.

\title{
KASKADIERIS NEIZPILDĀMĀKAI EPIZODEI
}

\author{
Raivis Bičevskis, Dr. phil., LU asociētais profesors
}

Vācu filozofs Odo Markvards (19282015), kurš sevi pieskaitīja pēckara skeptiskās paaudzes pulkam, vienā no saviem tekstiem, kas veltīts mūsdienu zinātņu un filozofijas liktenim, izsakās, ka filozofs vienmēr bijis brīvs pēddzinis, kurš savos pētījumos med̄̄ it visur un šḳērso visdažādāko disciplīnu, zinātnuu, mākslu un ikdienas dzīves jomu robežas. Tāpēc ekspertu kultūras laikmetā ir grūti filozofu novietot un "noḳert" un vina teikto klasificēt. Sekas tam ir jau kopš Platona vēstulēm pazīstamie filozofijas vērtējumi, kuru skala sniedzas no apbrīnas līdz nicinājumam un plecu raustīšanai. Taču ir tā, ka ekspertu kultūrā reiz pienāk brīdis, kad eksperti pieklust vai rausta plecus nevis tāpēc, ka filozofu izteikumi būtu dīvaini un pārāk neieklaujami, piem., reālpolitikas vai sociopsihologijas pielietojumā, bet gan tāpēc, ka pati realitāte, paši fenomeni, par kuriem ir runa, ir pārāk kompleksi vai vispār netverami, lai gan piln̄̄gi un nepārprotami "reāli”. Tad, saka U. Markvards, filozofs parādās kā kaskadieris neizpildāmākai epizodei, kuras paveikšanu 
neuzṇemas neviens eksperts, neuzṇemas neviens ārpus filozofijas. ${ }^{1}$

Māris Kūlis ir kēeries pie uzdevuma, kas atgādina šādu U. Markvarda piesaukto lomu kaskadiera neizpildāmākai epizodei: par Islāma valsti, par džihādu un terorisma draudiem, kas nāk no islāma radikāliem strāvojumiem, ir informēts, šķiet, ikviens Rietumu sabiedrības loceklis, sākot ar sociālo tīklu vidējo patērētāju, skolēniem skolās un beidzot ar pētniecības institūtu un centru darbiniekiem, kuri saistīti ar savu nacionālo valstu sociālo un politisko problēmu un starptautisko politisko procesu izpēti. Tomēr mēǵināt šos ar mūsdienu globalizētās sabiedrības iekšêjiem konfliktiem un negaidīti tiešiem, nepastarpināti nežēlīgiem nāves draudiem saistītos fenomenus aplūkot, kā arī skaidrot plašākā kultūru un civilizāciju attīstības un savstarpējo attiecību vēsturiskā un - svarīgi! - nākotnes perspektīvā, - to pašlaik uzņemas darìt pavisam nedaudzi. Vēl vairāk: skatīt Islāma valsti ne tikai kā labi drīz iznīcināmu ḷaunuma centru vai draudu, ar kuru jātiek galā sabiedroto spēku koalīcijai vai tās atbalstītiem reǵionāliem militāriem spēkiem, bet arī kā fenomenu, kas vairāk, daudz vairāk pastāsta par Eiropu un Rietumiem, - šāds uzdevums nu reiz ir īsts kaskadiera cien̄̄gs pienākums, neizpildāmākā epizode, kas prasa iedziḷināties ne tikai islāma kultūras līdzšinējā vēsturē un, in concreto, Islāma valsts tapšanā un tās rašanās nosacījumos, bet arī Eiropas mūsdienu garīgajā situācijā un tās avotos. Uzṇemties risināt šādu uzdevumu nozīmētu atsaukt atmiṇā pašu Rietumu filozofu pašrefleksīvās prognozes un atskatus, kuros jautāts par Rietumu kultūras likteni. Uz to laikam gan spējīgs tikai un tieši filozofa izglītību ieguvis pētnieks, kura skatījums būtiski papildina $\operatorname{lī}_{\mathrm{d} z}$ šim islāma problemātikā latviski pausto. ${ }^{2}$ M. Kūlis arī uzsver šo apstākli grāmatas priekšvārdā: "Bez

Sk. Marquard, Odo (2016) Über die Unvermeidlichkeit der Geisteswissenschaften. Panteos, Athena; Rojek, Tim (Hrsg.) Texte zur Theorie der Geisteswissenschaften. Stuttgart, 253-266.

2 Norādes uz latviešu valodā rakstīto sk. Kūlis, Māris (2018) Terorisma krustugunīs: Islāma valsts. Rīga : FSI, 24-25. Tālāk atsauces uz grāmatu recenzijas tekstā, grāmatas nosaukumu saīsinot TK un pievienojot lapaspuses numuru. filozofijas vēstures zināšanām grāmata būtu krietni pliekanāka.” (TK 11. lpp.) Tik tiešām, stāsts par Islāma valsti "vienlaikus ir stāsts par mums pašiem - par mūsu vājumu un ḷaušanos draudiem, par intelektuālo apmulsumu un par kultūras vitalitāti” (TK 13. lpp.) vai - par kultūras vitalitātes avotiem, trūkumu un tā sekām.

Grāmatas autors jau ievadā citē pētniekus, kas tieši Islāma valsts saasinātajā politiskajā situācijā saskata to, ka civilizācijas un kultūras saistītas ar ideāliem, ne tikai materiālajām vērtībām un ka šie ideāli ir tikuši un tiek aizstāvēti bezkompromisa cīņās (sal. 20. lpp.). Vai Rietumu demokrātiju pamatvērtības kāds ir gatavs aizstāvēt ar tikpat kaislīgu un nepiekāpīgu patosu, kādu pauž daudzi islāma pārstāvji? Skaidrs, ka šis jautājums ir retorisks un savā būtībā arī maldinošs: M. Kūlis paver lasītājam ieskatu islāma sabiedrībās un politisko grupējumu dzīvē, kurā lıoti labi iedzīvojušies Rietumos izveidoti polittehnologiju musturi un moderno mediju vides pielāgojumi (īpaši sk. TK 343. lpp. un tālāk). Islāma radikālās kustības zina vai pašlaik ḷoti ātri apgūst to, kā manipulēt ar cilvēku prātiem un emocijām un kā iegūt atbalstu ar mediju, propagandas un baiḷ materiālo un psihologisko tehniku palīdzību. Norādes un apraksti, kas skar Islāma valsts propagandu (kas grāmatā papildināti ar ilustratîvo materiālu), noteikti ir viens no veiksmīgākajiem un arī informācijas ziṇā svarīgākajiem grāmatas nodaḷu saturiskajiem aspektiem, kam ir arī loti praktiska nozīme: interneta dz̄̄lēs atrodamā informācija skar mūs tikpat tieši kā pēkšņa kultūru saskares un plaisu pieredze, un visbiežāk esam nesagatavoti tās uztverei un izvērtējumam. Temats "propaganda, ideologija, nekritiski uztverta mediju informācija un viltus ziņas" noteikti kḷūs tikai aktuālāks. Cik zināms recenzentam, M. Kūlis šo tematu (atkal filozofiskā patiesības idejas zuduma un patiesības izpratnes perspektīvā) turpinās jaunās publikācijās, un tās gan jau nesīs vēl papildu atziņas un noškīirumus.

Grāmata sadalīta nodaļās, kas apkopotas trīs daḷās Augsne, Tapšana un Ideja. Katrā no tām runa ir ne tikai par Islāma valsts vēsturisku rekonstrukciju vai ar to saistītu faktu uzskaiti, bet gan arī par vēsturisko un politisko procesu neviennozīmīgumu un interpretējamību. Autors labi parāda, cik kompleksa un sarežǵīta 
ir Rietumu valstu (arī savstarpēji pretrunīgā) pozīcija pret Islāma valsti un politisko islāmu kopumā.

Vēl viens svarīgs grāmatas aspekts ir tās iekārtojums: daḷām un nodaḷām seko ne tikai piezīmes un paskaidrojumi, bet arī terminu glosārijs, literatūras saraksts un personu un organizāciju rādītājs. Te M. Kūlis balstās uz jau latviski paveikto un sadarbībā ar islāma ekspertiem noskaidroto. Lasītāja darbs, lasot grāmatu, tādējādi ir atvieglināts, jo iespējams apgūt un lietot ar islāma pasauli saistîtus terminus un izmantot personvārdu atveidi. Bieži mums pietrūkst valodas skanējuma un nianšu, lai runātu par realitāti un vispār l̦autu tai parādīties savā "reālumā", tāpēc valodiski apsvērumi un diferences nebūt nav nevajadzīgs, bet gan tieši l̦oti vajadzīgs filozofiskas analīzes instruments.

Autors ir k̦ēries pie grāmatas 2. papildinātā izdevuma veidošanas. Varbūt tajā varēs atrast vēl tiešāku un niansētāku uzsvaru uz to, kas pausts TK nodaḷā Nobeigums bez gala (381. lpp. un tālāk). Grāmata noslēdzas ar rekursu uz F. Nīčes vārdiem par Dieva nāvi un baisi kārdinošajām un mānīgajām robežām starp dzīvību un nāvi, kuras pārkāpjot Islāma valsts radīja vīziju, kas savā metafiziskajā tiešumā un škietamajā pretstatā Rietumu patērētājsabiedrības vājajām labklājības vīzijām runāja asiṇu un ideju valodā (TK 398. lpp.). Rietumu "politkorektuma maigais, taču nepagurstošais spiediens ikvienu [šaubu par "mūsu" dzīvesveida pareizumu - R. B.] grubuli nogludina līdz glumam spīdumam" (TK 224. 1pp.) - tam iepretim islāma radikālisms noliek skaudri pirmatnēju un tiešu tikšanos ar eksistenciāliem "būt vai nebūt" un "kā būt" jautājumiem l̦oti k̦ermeniskā un iluzori skaidrā formā. Šis salikums (rekurss uz F. Nīči un Islāma valsts spēli ar dzīvību un nāvi) varētu vest pie jauniem atklājumiem atkal jau ne tikai par politisko islāmu, bet gan par "mums". Varbūt F. Nīčes vārds tik tiešām nav nejaušs viesis grāmatas noslēgumā: viṇa aprakstitais Rietumu nihilisms (tas, ka nav atbildes uz jautājumu “kāpēc?” - kāpēc rīkoties, aizstāvēt kādas vērtības, kāpēc dzīvot un kāpēc neieslīgt vispārējā vardarbībā un haosā) ir ne tikai Rietumu vājums, bet gan it kā entropisks Nekas (nihil), kas ievelk un apēd visu kultūru un laikmetu vērtības un idejas. Varbūt tas, kas grāmatā minēts kā eiropiešu apjukuma avots, vienlaikus ir arī Vakarzemes, Okcidenta varenuma iemesls? Tieši tāds - kā dievu, vērtību, svētumu un tēvzemju anihilators - tas arī varēja parādīties kā Rietumu pārākuma un varas centrs. Citiem vārdiem: tieši Eiropas un Rietumu civilizācijas būtības un likteņa izpratnē uz islāma un citu pasaules kultūru fona - vēl daudz darāmā. ${ }^{3}$ Par to liecina, piem., Richard Amesbury (Clemson University) publikācijas par kristietību un islāmu jauno labējo kustību Eiropas kontekstā un par eiropeisko modernitāti mūsdienu reliğisko, pseidoreliǵisko un populisma fenomenu kontekstā. Pasaules politiskās un sociālās vētras un negaisi spiež un dzen mūs aizvien no jauna un, aizvien mazāk slēpjoties no sevis, liek jautāt, kas esam un kas varam būt; ko varam vai nevaram, un kas ierobežo vai veicina šo varēšanu.

M. Kūḷa grāmata sniedz ļoti plašu faktoloǵisku un interpretatîvu materiālu visiem, kam interesē islāms, politiskie un sociālie procesi Tuvajos Austrumos un mūsdienu pasaulē kopumā, kultūru attiecības, kā arī Eiropas un Rietumu šodiena un nākotnes iespējas.

3 Tieši šādā aspektā šobrīd izraisījusies plaša un asi risināta diskusija par Martina Heidegera sniegtajām Rietumu nākotnes prognozēm un tagadnes diagnozēm, jo kopš 2014. gada Vitorio Klostermana izdevniecībā Heidegera Kopoto rakstu izdevuma ietvaros sākts publicēt viņa Melnās burtnīcas - piezīmes, kuras filozofs rakstīijis 20 . gadsimta 30 . un 40 . gados. Tajās viņš runā par Rietumu likteni un jaunlaiku nihilistisko garu, kas izvērsies kā cīna par planetāro varu. Cerams, ka šīs diskusijas interesantākie un būtiskākie aspekti būs drīzumā pieejami grāmatās arī latviešu valodā lasošajai publikai: Hermans, Frīdrihs Vilhelms fon; Alfjeri, Frančesko. Patiesība par Heidegera Melnajām burtnīcām (plānots publicēt 2018. gada novembrī); Bičevskis, Raivis. Heidegera pusē (plānots publicēt 2018. gada decembrī). 